\title{
Resilience on Human Trafficking Victims in West Java
}

\author{
IHSANA SABRIANI BORUALOGO \\ Fakultas Psikologi Unisba Jln. Tamansari No. 1 Bandung \\ e-mail: insana.sabriani@yahoo.com
}

\begin{abstract}
There are cities/districts in West Java which have high number of human trafficking cases. Human trafficking victims experienced psychological distress due to violence they have experienced. The aim of this research is to describe resilience on human trafficking by using theory from Michael Ungar. This research used descriptive method with purposive sampling technique. Samples taken are 33 women, age 15-23 years old, mostly graduated from junior high school ( 16 persons $=49 \%)$. Data was collected using resilience questionnaire CYRM-28 which created by Michael Ungar. Research findings showed $69.7 \%$ of victims have high resilience. In socio-ecological dimension, which is relationship with caregiver (mean $=3.96$ ) and context/sense of belonging (mean $=3.96$ ) have higher mean compare to individual dimension (mean $=3.79$ ). In socio-ecological dimension, psychological caregiving (mean $=4.15$ ) and spiritual (mean $=4.10$ ) are two important indicators which help individuals to become resilient. In individual dimension, personal skill (mean $=3.85$ ) is the important indicator which must be owned by individuals to become resilient.
\end{abstract}

Keywords: Resilience, Human Trafficking, Socio-Ecological

\section{Introduction}

Human trafficking is one of the serious problems in human life. Every human being has the rights to have freedom. Human trafficking is the second largest illegal industry globally behind the drug trade (Yea, 2010: 2).

UNODC (United Nations Office on Drugs and Crime) defines human trafficking as the recruitment, transportation, transfer, harbouring or receiving of persons by means of threat or use of force or other forms of coercion, abduction, fraud, deception, the abuse of power or a position of vulnerability, giving or receiving payments/benefits to achieve the consent of a person having control over another person for the purpose of exploitation (www.unodc.org). Exploitation shall include, at a minimum, the exploitation of the prostitution of others or other forms of sexual exploitation, forced labor or services, slavery or practices similar to slavery, servitude or the removal of organs (www. unodc.org).

There are 6.651 cases of human trafficking in Indonesia in the period of March 2005 until December 2014. Nurul Qoiriah from National Project Coordinator for Counter-Trafficking and Labor Migration Unit International Organization for Migration (IOM) said, having this high number of cases put Indonesia in the most human trafficking cases worldwide, amounting to $92.46 \%$ of total 7.193 victims worldwide. Most of the victims were adult women (4.888 persons) and girls (950 persons). West Java is in the first rank in term of the number of human trafficking cases. The number of victims in West Java reached 2.151 persons or $32.25 \%$ of the total number of the human trafficking in Indonesia (http://news.okezone.com/ human-trafficking-di-indonesia-tertinggi-didunia).

The newest report in 2017 on number of human trafficking cases in Indonesia showed that Indonesia is still in the highest position, even though the number of cases reported was declined. According to the US Embassy and Consulate website in Indonesia, the AntiTrafficking Unit of the Indonesian National Police's Criminal Investigation Unit reported 110 new case investigations during 2016. This number decreased from the previous year which had 221 cases (https://id.usembassy. org). Mahkamah Agung (The Supreme Court) reported 256 decisions in 2016 which

Received: August 17, 2017, Revision: April 11, 2018, Accepted: June 09, 2018

Print ISSN: 0215-8175; Online ISSN: 2303-2499. DOI: http://dx.doi.org/10.29313/mimbar.v34i1.2856.204-212

Accredited B based on the decree No.040/P/2014, valid on February, 18, 2014 until February, 18, 2019. Indexed by DOAJ, Sinta, IPI 
increased from 119 decisions in the previous year with a verdict of up to seven years in prison (https://id.usembassy.org).

Although the Government of Indonesia has made effort to overcome and prevent the occurrence of human trafficking cases, it seems that the community still does not have awareness to avoid themselves of being vulnerable to become human trafficking victims. There are still many people who are easily tricked by the traffickers who offer high-paying jobs. Based on the interview, the human trafficking victims said that the traffickers usually come to the villages to offer high-paying jobs to the villagers. The villagers who are having financial problems and really in need to have jobs, would easily interested in traffickers' offer. Traffickers usually offer jobs to young adult women. The jobs offered to them mostly are a waitress in a restaurant, a song guide girl in karaoke, or a masseuse in massage parlor.

Some districts (cities/regencies) in West Java, such as Indramayu Regency, Bandung Barat Regency, Sukabumi Regency, Bogor City, Cirebon Regency, and Tasikmalaya City are the districts which have high number of human trafficking cases. This condition is certainly very apprehensive. According to Neng Hannah Hakim, Director of RESIC (Research of Environment and Self Independent Capacity), there are several causes which make adult women and girls being vulnerable to become human trafficking victims. Poverty, low level of education, early marriage that easily ended in divorce, a value in the society which assumes that girls are a family asset, are some reasons which cause women and girls being trafficked, even by their own parents (http://nasional.tempo. co/read/news/korban-perdagangan-wanitaterbanyak-dari-jawa-barat).

The high rate of poverty forces almost the whole family members to earn something for living, including mothers and children (Borualogo, 2004: 289). In one side, this condition gives profits to family because the source of income is more than one (Borualogo, 2004 : 289). But in the other side, this will be risking the family's life. Financial problems can cause individuals to think irrationally in an effort to meet family needs. When there is a high-paying job offer, the individual is more likely to accept it, regardless of the type of the job, what skills are needed, whether they have skills which suit the requirements or not, and the possibility of working away from their hometown without assurance of certainty and security guarantees. In fact, these conditions would highly and vulnerably become the entrance to being human trafficking victims.

In addition to financial problems, low education and lack of skills are also suspected as two factors causing individuals being trapped into human trafficking victims. The low level of education is one of the causes of the low Human Development Index (HDI) of Indonesia compared to other countries in the world, as well as in Asia (Borualogo, 2006: 395). The Human Development Report released by UNDP (United Nations Development Program) in 2017 showed that Indonesia was ranked 113th in the world (Human Development Index $=0.689$ ) (hdr. undp.org). The data indicated there were $18.1 \%$ of elementary school students dropped out of school, and only $47.3 \%$ of individuals aged 25 and older who have completed junior secondary education (hdr.undp.org). The low level of education became the factor causing the individual to be easily trapped into being human trafficking victims. Lack of knowledge, lack of skill, and unable to think and analyze the problem objectively are factors which make them vulnerable to become victims.

Based on interview which was conducted by the researcher on human trafficking victims, they said that they did not know that they would be traded. Typically, human trafficking victims are from low socioeconomic groups and low level of education. They were offered high-paying jobs outside the city or even abroad. In some cases, even before they started working, they have already acquired facilities which made them believe that they would get a good job. In fact, these facilities would be stopped, because these facilities were only used to make the victims interested to join the jobs. When they have been trapped in human trafficking, these facilities were considered as debt which the victims must pay using the wages they receive from the traffickers. Therefore, the wages they have received being cut-off and they have to pay their debts.

In general, those who were vulnerable being victims of human trafficking were individuals who have financial problems and low level of education. They were easily being tricked by traffickers. Financial problems are the main source which caused individuals accepted high-paying job offers from traffickers. Those who are having financial problems find it difficult to find a 
way out of their problems and feel helpless. It weakens their ability to think, unable to analyze the risks, and failed to see whether the info from the traffickers were accurate or not. Therefore, they were being vulnerable to become human trafficking victims.

Some victims were forced into prostitution, while others were forced to work without having adequate wages, and even tortured by employers. The victims were in a very difficult situation. Mostly, they are unable to escape from being a victim. Though some of them were brave enough to run out and went back to their family.

The human trafficking victims experienced psychological problems due to pressure they have been experiencing. They feel depressed and embarrassed because they were considered as bad person by people in their community. They even fear to interact with people in their neighborhood. They feel helpless, being rejected by the community, and feel unsecure. Some of them have lost their self-esteem and feel undignity.

Based on the interview with the victims, they said that some of them could overcome the psychological pressure and continue their life. Even some of them could help other victims to overcome the pressure. They also could provide info for people in their area of living to avoid themselves to be a victim. But in the other side, many victims were still experiencing severe psychological distress, even remaining susceptible to becoming victims again.

The individual ability to overcome and bounce back from psychological pressure called resilience. Rutter (2006 in Ungar, 2012: 34) said, resilience is defined as a relative resistance to environmental risk experiences, the overcoming of stress or adversity, or a relatively good outcome despite risk experiences. Based on this definition, resilience refers to individual capacity to bounce back after experiencing stress and adversity. In psychological context, Ungar (2012) explained resilience is not only in individual capacity, but also socio-ecological context which helps them to become resilient. Ungar (2012: 56) defines resilience as both the capacity of individuals to navigate their way to the psychological, social, cultural, and physical resources that sustain their well-being, and their capacity individually and collectively to negotiate for these resources to be provided in culturally meaningful ways. This definition supports the proposition that a system fulfills its purpose when it functions normally under stress and, therefore, shows resilience (Ungar, 2012 : 56). Based on this definition, it can be understood that resilience does not only refer to individual capacity, but also refers to socio-ecological condition of the individuals. Ungar explains there are three dimensions of resilience, which are (1) individual, (2) relationship with caregivers, dan (3) context/ sense of belonging (Borualogo, 2017: 223224). There are three indicators in individual dimension, which are: (1) individual personal skills, (2) individual peer support, and (3) individual social skills (Borualogo, 2017: 223-224). In the dimension of relationship with caregivers, there are two indicators, which are: (1) physical caregiving, and (2) psychological caregiving (Borualogo, 2017: 224). In the dimension of context/sense of belonging, there are three indicators, which are: (1) spiritual, (2) educational, and (3) cultural (Borualogo, 2017: 224).

On the basis of consideration that this theory of resilience from Michael Ungar is using a socio-ecological approach, then this theory was used to describe the resilience of human trafficking victims in West Java, especially in Kabupaten (Regency) Indramayu, Kabupaten Bandung Barat, Kabupaten Sukabumi, Kota (city) Bogor, Kabupaten Cirebon, and Kota Tasikmalaya.

\section{Research Method}

Descriptive method was used in this research to explain about the resilience of human trafficking victims and the dimensions of resilience. The sampling technique used in this research was purposive non-probability technique. This technique is used when researchers do not get a complete list of all members of the population to be sampled in the study. In addition, the subject of research in this area is difficult to recognize, so the research team requested assistance to P2TP2A and related NGOs to determine and requested human trafficking victims who are willing to be a research sample. The study sample criteria are: (1) female, (2) aged 15-23 years, (3) recorded in P2TP2A/LSM in West Java, and (4) willing to be a respondent.

CYRM-28 for youth which designed by Michael Ungar and Linda Liebenberg was used as a gauge instrument in this research. The original version of the measuring instrument is in English. The researcher has obtained 
written permission from Michael Ungar to use this measurement instrument and the researcher is solely responsible for permission to use the measurement instrument. The measurement instrument has been translated into Bahasa Indonesia by Ihsana Sabriani Borualogo in accordance with translation procedures of cross-cultural measurement instruments. The translation process does not only translate from English into Bahasa Indonesia, but also takes into account the cultural context of Indonesia (Van de Vijver \& Hambleton: 1996).

The measurement instrument is arranged in the form of Likert scale with alternative answer (1) not at all explaining; (2) a little explaining; (3) somewhat explaining; (4) quite a bit explaining; and (5) a lot explaining.

Validation of CYRM-28 has been tested by Michael Ungar, Linda Liebenberg, and Fons van de Vijver using exploratory and confirmatory factor analysis. Result confirmed that CYRM-28 show adequate psychometric properties (Ungar, Liebenberg, van de Vijver, 2011: 219). Internal reliability of the three components on the CYRM-28 was assessed using Cronbach's a, paired sample t tests, and interclass correlation coefficients on Time 1 and Time 2 responses. Cronbach's a ranged from .65 to .91 and was acceptable in all cases (Ungar, Liebenberg, van de Vijver, 2011: 221).

Descriptive analysis technique was used in this research. By using this analysis technique, researchers could explain the means on each dimension and each indicator of the measurement instrument. Therefore, researcher could explain the highest means of dimensions and indicators as individual strength and socio-ecological sources which can help individual to become resilient.

\section{Results and Discussion}

Demographic in table 1 data showed that most of the human trafficking victims's education were graduated from junior high school (16 persons $=49 \%$ ). There are 33\% (11 persons) graduated from senior high school, and $18 \%$ (6 persons) graduated from elementary school. This showed that most of the victims of human trafficking have low level of education. This is in accordance with the statement from Neng Hannah Hakim, Director of RESIC (Research of Environment and Self Independent Capacity), that low level of education is one factor which caused individuals being vulnerable to become victims of human trafficking ( $h$ ttp://nasional. tempo.co/read/news/korban-perdaganganwanita-terbanyak-dari-jawa-barat).

All of the samples of this research were victims of sexual exploitation which have been offered high paid job as waitress in restaurants, a song guide girl in karaoke, or a masseuse in massage parlor. But in fact, they have been tricked to become sex worker and being exploited without getting wages as promised. This is in accordance with the global report from UNODC (United Nations Office on Drugs and Crime) which said that sexual exploitation was the most frequent cases happened (79\%) (www.unodc.org).

The level of education of parents'of human trafficking victims is also low. There are $52 \%$ (17 persons) of father's of human trafficking victims and $58 \%$ (19 persons) of mother's of human trafficking victims only graduated from elementary school. There are $30 \%$ (10 persons) of the father's of human trafficking victims and $30 \%$ (10 persons) of the mother's of human trafficking victims graduated from junior high school. Only $18 \%$ (6 persons) of the father's of human trafficking victims and $12 \%$ (4 persons) of the mother's of human trafficking victims graduated from senior high school. This low-level education of the parents' of human trafficking victims has become one of the factors which caused their children to become the victims of human trafficking. A very low parental knowledge about trafficking made them unaware about the possibility of their children to become victims. When they get offers of high-paying job opportunities for their children from the traffickers, parents easily believe in them. They have very little information about the possibility of fraud in job offers which promise high paid wages for their children, whereas their children have no skills. Economic demands, low level of education, and lack of information, allow parents to accept the job offers for their children, which then caused their children becoming victims of human trafficking.

Although the demographic data show that the level of education of both victims and parents are low, but only $18 \%$ of the victims really realized that the low level of education is one of the factors which caused them vulnerable to become the victims. Lack of education caused them to not having sufficient knowledge to avoid traffickers and 
Table 1

Demographic Data

\begin{tabular}{|c|c|c|c|c|c|c|c|c|}
\hline No & Subject & Age & Education & $\begin{array}{l}\text { Father's } \\
\text { education }\end{array}$ & $\begin{array}{l}\text { Father's } \\
\text { job }\end{array}$ & $\begin{array}{l}\text { Mother's } \\
\text { education }\end{array}$ & $\begin{array}{l}\text { Mother's } \\
\text { job }\end{array}$ & $\begin{array}{c}\text { Reason become a } \\
\text { victim }\end{array}$ \\
\hline 1 & IS & 16 & SMP & SMP & A driver & SMP & Trader & Low education \\
\hline 2 & $\mathrm{R}$ & 18 & SMA & SD & A heaver & SD & $\begin{array}{l}\text { A } \\
\text { Housewife }\end{array}$ & Financial problem \\
\hline 3 & $A$ & 16 & SMP & SMP & $\begin{array}{l}\text { A } \\
\text { motorcycle } \\
\text { driver }\end{array}$ & SMP & $\begin{array}{l}\text { A } \\
\text { Housewife }\end{array}$ & Being tricked \\
\hline 4 & MK & 18 & SMA & SD & A farmer & SD & $\begin{array}{l}\text { A } \\
\text { Housewife }\end{array}$ & Financial problem \\
\hline 5 & Y & 17 & SMP & SMP & A heaver & SMP & $\begin{array}{l}\text { A } \\
\text { Housewife }\end{array}$ & Financial problem \\
\hline 6 & $\mathrm{~F}$ & 17 & SMP & SD & A farmer & SD & Trader & $\begin{array}{l}\text { Followed friend's } \\
\text { suggestion }\end{array}$ \\
\hline 7 & SD & 15 & SMP & SMA & A trader & SMP & Farmer & Being tricked \\
\hline 8 & FO & 16 & SMP & SMP & A farmer & SMP & $\begin{array}{l}\text { A } \\
\text { Housewife }\end{array}$ & Being tricked \\
\hline 9 & D & 15 & SMP & SMA & $\begin{array}{l}\text { A } \\
\text { mechanic }\end{array}$ & SD & Trader & Financial problem \\
\hline 10 & MA & 18 & SMP & SD & A farmer & SD & Trader & Being tricked \\
\hline 11 & SM & 16 & SMP & SMP & A heaver & SMP & A maid & Being sold by parents \\
\hline 12 & $\mathrm{HZ}$ & 19 & SMP & SMP & A heaver & SMP & A maid & Being sold by parents \\
\hline 13 & DN & 23 & SMK & SMA & $\begin{array}{l}\text { A } \\
\text { traditional } \\
\text { healer }\end{array}$ & SMA & $\begin{array}{l}\text { A } \\
\text { Housewife }\end{array}$ & Being tricked \\
\hline 14 & DU & 23 & SD & SD & A trader & SD & Trader & Being tricked \\
\hline 15 & UU & 23 & SMA & SMA & A heaver & SMA & $\begin{array}{l}\text { A } \\
\text { Housewife }\end{array}$ & Financial problem \\
\hline 16 & K & 22 & SMA & SMA & A heaver & SMA & $\begin{array}{l}\text { A } \\
\text { Housewife }\end{array}$ & Being tricked \\
\hline 17 & US & 21 & SMA & SMA & A heaver & SMA & $\begin{array}{l}\text { A } \\
\text { Housewife }\end{array}$ & Being tricked \\
\hline 18 & FRS & 18 & SMP & SD & A farmer & SD & A maid & Being tricked \\
\hline 19 & RD & 18 & SMP & SMP & $\begin{array}{l}\text { A } \\
\text { mechanic }\end{array}$ & SMP & $\begin{array}{l}\text { A } \\
\text { Housewife }\end{array}$ & Being tricked \\
\hline 20 & DS & 18 & SD & SD & A driver & SD & A maid & $\begin{array}{l}\text { Followed friend's } \\
\text { suggestion }\end{array}$ \\
\hline 21 & PD & 18 & SMP & SMP & $\begin{array}{l}\text { A trader/ } \\
\text { merchant }\end{array}$ & SMP & $\begin{array}{l}\text { A } \\
\text { Housewife }\end{array}$ & $\begin{array}{l}\text { Need to have fancy } \\
\text { life }\end{array}$ \\
\hline 22 & AR & 16 & SD & SD & A farmer & SD & $\begin{array}{l}\text { A } \\
\text { Housewife }\end{array}$ & Low education \\
\hline 23 & $\mathrm{FL}$ & 18 & SMP & SMP & $\begin{array}{l}\text { An office } \\
\text { boy }\end{array}$ & SD & Trader & Low education \\
\hline 24 & IN & 17 & SMP & SMP & $\begin{array}{l}\text { A } \\
\text { motorcycle } \\
\text { driver }\end{array}$ & SMP & Trader & Being tricked \\
\hline 25 & YS & 20 & SMA & SD & A trader & SD & $\begin{array}{l}\text { A } \\
\text { Housewife }\end{array}$ & Being tricked \\
\hline 26 & $\mathrm{~N}$ & 19 & SMA & SD & A trader & SD & $\begin{array}{l}\text { A } \\
\text { Housewife }\end{array}$ & Low education \\
\hline 27 & $\mathrm{AH}$ & 17 & SD & SD & A trader & SD & $\begin{array}{l}\text { A } \\
\text { Housewife }\end{array}$ & Being tricked \\
\hline 28 & SI & 19 & SD & SD & A farmer & SD & $\begin{array}{l}\text { A } \\
\text { Housewife }\end{array}$ & Being tricked \\
\hline 29 & DK & 19 & SMP & SD & A heaver & SD & $\begin{array}{l}\text { A } \\
\text { Housewife }\end{array}$ & Being tricked \\
\hline 30 & MM & 20 & SMA & SD & A trader & SD & $\begin{array}{l}\text { A } \\
\text { Housewife }\end{array}$ & Low education \\
\hline
\end{tabular}




\begin{tabular}{llllllll}
31 & N & 18 & SD & SD & A farmer & SD & $\begin{array}{l}\text { A } \\
\text { Housewife }\end{array}$ \\
32 & EN & 17 & SMA & SD & A heaver & SD & $\begin{array}{l}\text { A } \\
\text { Housewife }\end{array}$ \\
33 & NN & 21 & SMA & SD & A driver & SD & $\begin{array}{l}\text { A } \\
\text { Housewife }\end{array}$ \\
\hline
\end{tabular}

Note:

$\mathrm{SD}=$ Elementary school

SMP = Junior high school

SMA = Senior high school

not becoming victims of human trafficking. Thus, as many as $52 \%$ (17 persons) of human trafficking victims said they became victims because of being tricked by traffickers who offered high paid jobs. Later they found themselves being sold and forced to work as sex workers. As much as $15 \%$ ( 5 persons) of the victims were aware that their low economic conditions also caused them to be trapped as victims of human trafficking. Even $6 \%$ ( 2 persons) of the victims admitted that they were sold by their parents to the traffickers due to severe economic problems.

To be able to determine individual resilience, the researcher categorized the level of resilience based on the range of the resilience score, which explained below.

Range $(R)=$ the highest score - the lowest score $=128-75=53$

Number of class $(\mathrm{NoC})=2$ (high and low)

Interval $(P)=\frac{R}{N n C}=\frac{53}{2}=26.5=27$

Based on this range calculation, then we classified the level of resilience of the victims as shown in the Table 2.

\section{Table 2 \\ Classification of the level of resilience of the victims}

\begin{tabular}{cccc}
\cline { 1 - 1 } Resilience & Interval & F & \% \\
\hline High & $102-128$ & 23 & $69.7 \%$ \\
Low & $75-101$ & 10 & $30.3 \%$ \\
Total & & 33 & $100 \%$
\end{tabular}

Table 2 showed there are $69.7 \%$ (23 persons) have high level of resilience, and $30.3 \%$ (10 persons) have low level of resilience. This result showed that most human trafficking victims were resilient. It means the human trafficking victims have the capacity to bounce back after experiencing adversity and sex abuse. This is a very interesting finding since the human trafficking victims actually have experienced stressful event which predicted could cause them hard to bounce back and to continue their life. But rather then the data showed that $69.7 \%$ of the victims were resilient.

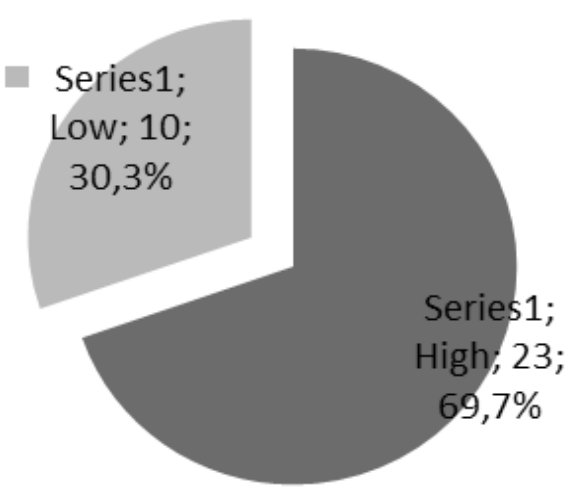

Figure 1

Percentage of the level of resilience of the victims

To be able to understand what factors helped the victims to bounce back, the researcher calculated the means of each dimension and each indicator of the resilience to see the highest means.

As it explained before, resilience was measured using CYRM-28 which constructed by Michael Ungar and Linda Liebenberg. This instrument measures three dimensions of resilience, which are (1) individual, (2) relationship with caregiver, and (3) context/ sense of belonging (Borualogo, 2017: 223224). The table 3 presents the means of these three dimensions of resilience.

\section{Table 3}

Means of Dimension of Resilience

\begin{tabular}{lll}
\hline No & Dimension & Mean \\
\hline 1 & Individual & 3.79 \\
2 & Relationship with caregiver & 3.96 \\
3 & Context / sense of belonging & 3.96 \\
\hline
\end{tabular}




\section{Socio-ecological Dimension}

Table 3 showed the dimension of relationship with caregiver and context/sense of belonging have the same mean value of (3.96). Individual has the lowest mean (3.79) compare to other dimensions.

Ungar (2012: 56) explained that resilience is not only about individual capacity. Ungar (2012: 56) said, socio-ecological factor is also important. This can be translated as functioning in a socially and culturally acceptable way or in accordance with socially accepted rules (Ungar, 2012: 56). This functionality within social processes is reflected in Ungar's (2011) definition of resilience (Ungar, 2012: 56) who stated that socio-ecological factors mean availability of resources out of individual, such as psychological, social, cultural, and physical resources that sustain their well-being (Ungar, 2012: 56).

Based on data shown on Table 3, we can see that socio-ecological factors (relationship with caregiver and context/sense of belonging) have higher mean compared to individual capacity. This happened because human trafficking victims considered of having no capacity to overcome adversities because of they were victims of human trafficking. They were in heavy psychological pressure and feel so depressed. They actually have already tried to solve their problems, but if they only rely on their own capacity, they were still having difficulty to bounce back from the adversities and pressure they have experienced. They spent their days crying and isolated themselves in their room not wanted to socialize with people, even with their family. This of course did not help them to solve their problems, and even made them more depressed and sadder. After spending so much time crying and regretting their life, they finally have a little willing to start social interaction with family, then with community. They started their social activities in their neighborhood. But it was not easy because sometimes they still experienced the pressure which made them stressed, cried, and isolated themselves again from their community.

Due to social problems which caused by human trafficking cases, the victims of human trafficking are very often being judged negatively by their community. The community judged them that it was their own fault to become the victims. But of course not all the people in the community judged them negatively. The victims of human trafficking saw there were resources from their community which can help them overcome the adversities. With their own capacity, they saw socio ecological resources which they can be accessed. They also saw that there are values of caring and willing to help from their community.

By seeing there were socio-ecological resources, which they received from their caregiver and the context/sense of belonging, the victims then navigated themselves to approach the socio-ecological resources. They also negotiated some help which they needed to have from socio-ecological resources. They considered meaningful socio-ecological resources which will help them solving their problems, whether it were the caregiver or the context/ sense of belonging. Although some people in their community judged them negatively, but there were still socioecological resources which can be accessed by individuals. This can be understood in the Indonesian context which has collective culture. In the collective culture, people helping each other out and even giving some supports, whether psychologically, socially, culturally, and physically to help people overcome the adversities and bounce back.

\section{Individual Dimension}

Besides socio-ecological dimension, the individual capacity is also important for individuals to be resilient. Having individual capacity allows the victims of human trafficking to navigate themselves to available and accessible resources. They are also able to negotiate ecological resources and choose meaningful resources which have competency and can be trusted to help them to become resilient.

The capacity to navigate and negotiate is important for individuals to become resilient (Ungar, 2012). With this capacity to navigate and negotiate, individuals can choose socioecological resources to help them overcome their adversities in culturally meaningful ways. At the end, individuals become resilient. Collective culture in Indonesian is one of the socio-ecological factors which support acceleration for the victims of human trafficking to bounce back and resilient.

After knowing which dimension has the highest mean on the description above, now we are going to describe the mean of each indicator from those three dimensions, so that we can understand the highest mean of 
each indicator.

\section{Table 4}

\section{Mean of Resilience Indicators}

\begin{tabular}{|c|c|c|}
\hline No. & Dimension / Indicators & Mean \\
\hline \multirow[t]{4}{*}{1.} & Individual dimension & \\
\hline & - Personal skill indicator & 3.85 \\
\hline & - Peer support indicator & 3.71 \\
\hline & - Social skill indicator & 3.75 \\
\hline \multirow[t]{3}{*}{2.} & $\begin{array}{l}\text { Relationship with caregiver } \\
\text { dimension }\end{array}$ & \\
\hline & - Physical caregiving indicator & 3.50 \\
\hline & indicator & 4.15 \\
\hline \multirow[t]{4}{*}{3.} & $\begin{array}{l}\text { Context/sense of belonging } \\
\text { dimension }\end{array}$ & \\
\hline & - Spiritual dimension & 4.10 \\
\hline & - Education dimension & 3.70 \\
\hline & - Cultural dimension & 4.00 \\
\hline
\end{tabular}

Table 4 showed the highest mean on each dimension. In individual dimension, the highest mean was in personal skill indicator (mean $=3.85)$. In relationship with caregiver, the highest mean was in psychological caregiving indicator (mean $=4.15$ ). In the context/sense of belonging dimension, the highest mean was in the spiritual indicator (mean $=4.10)$.

In their relationship with caregiver, the victims of human trafficking valued the psychological caregiving (mean $=4.15$ ) as the very important aspect for individuals to help them being resilient compared to physical caregiving. Caring and understanding which individuals received from parents while they were becoming the victims of human trafficking had helped them built their own safety feeling. They felt accepted and understood by parents, therefore they were going to have the courage to start the social interaction again. While being around by parents, they assured that parents would help them and protect them while they were feeling stressed being the victims of human trafficking. Safety feelings which waken by caring and understanding from parents helped the individuals to bounce back and overcome their adversities.

In the context/sense of belonging dimension, spiritual indicator has the highest mean (mean $=4.10$ ). Individuals valued the spiritual faith as the strengthening resource to overcome adversities. They accepted this unwanted condition as a destiny. They also asked for forgiveness to God for their mistakes and sins. By following religious activities, they felt peace in mind and reduce the stressed feelings. They also participated actively in the religious communities to fill their daily activities with meaningful ways.

In this context/sense of belonging dimension, individual did not value high on the education indicator as the aspect which help them resilient (mean $=3.70$ ). Individuals also didn't see the education as an important aspect in socio-ecological context. But spiritual values both from within individuals and socio-ecological which shown could help individuals to bounce back from adversities.

Although the individual dimension has the lowest mean (mean $=3.79$ ) as shown in table 3, individual dimension is also considered important in helping individuals to be resilient. Personal skill indicator has the highest mean among other indicators in individual dimension (mean $=3.85$ ) as shown in table 4. It means, human trafficking victims agreed that personal skill is the important capacity to help the victims resilient. By having personal skill, individuals understand that they have strength and capacity to overcome their problems and not stressed easily while having problems. By having personal skill, individuals have the capacity to navigate and negotiate towards socio-ecological resources which would help individuals to be resilient. The capacity to navigate towards available and accessible socio-ecological resources and the capacity to negotiate to those resources are basic capacities which need to be owned by individuals to be resilient (Ungar, 2012).

\section{Conclusion}

Most human trafficking victims have the ability to bounce back and continue their life. In other wording, they are resilient.

Socio-ecological factor is the important factor/dimension which helps individuals to bounce back. Collective culture in Indonesia gives the opportunities to individuals to get help from their environment while they are facing adversities. Good relationship with caregiver and context/sense of belonging are socio ecological factors which were available and accessible by individuals to bounce back and become resilient.

Caring and understanding which shown by parents as caregiver are important aspects 
which help individuals to bounce back. Individuals feel safety and assure that parents will help them while they are facing adversities as the victims of human trafficking.

In the dimension of context/sense of belonging, spiritual is an important aspect which helps individuals to be resilient. Spiritual belief becomes strength of resources for the victims of human trafficking to be resilient.

In individual dimension, personal skill is an important indicator which has to be possessed by individuals to be resilient. Personal skill includes capacity to overcome problems and assurance that individuals have personal strength which can be used while they are facing adversities. By having personal skill, individuals are able to navigate themselves towards available and accessible resources from the environment. By having personal skill, individuals are also able to negotiate which resources can be counted on to help individuals.

By knowing that socio-ecological dimension is a very important factor for helping individual to become resilient, therefore social environment needs to provide resources which can be accessed easily by individuals while they are facing adversities. Availability of the resources from the environment will help individuals to navigate and negotiate those resources to help them bounce back.

The victims of human trafficking in six cities/regencies in West Java are considered psychological caregiving as an important resource to help them bounce back. By receiving caring and understanding from parents, they felt that parents understood their condition. Therefore, it can be suggested for parents to provide accessible psychological caregiving while individuals facing adversities. By giving caring and understanding to individuals, parents also could help individuals to avoid themselves from being vulnerable. Individuals need to enhance their knowledge and awareness to protect themselves from becoming the victims again.

Spiritual is also an important aspect which helped individuals to bounce back. Therefore, it can be suggested for individuals to accept their condition as a destiny from God. It is also needed to strengthen their spiritual belief that God will help individuals when they have close relationship with God. Individuals need to participate actively in religious activities to strengthen themselves.

Individuals who are vulnerable to human trafficking are individuals who have low levels of education and come from low socioeconomic groups. Therefore, it is necessary to conduct a comprehensive effort from the government by improving the education of the community to avoid the vulnerability of being victimized. Communities need to be reminded of the dangers of human trafficking, either through village officials or through community leaders.

\section{Acknowledge}

Thank you to Kemenristek DIKTI which has funded this research through Penelitian Produk Terapan schema in the year 2016/2017.

Thank you to Drs. Hedi Wahyudi, M.Psi and Suhana, M.Psi who have helped in the first stage of the preparation research, and the students who have helped on the process of data collection.

\section{References}

Borualogo, Ihsana Sabriani (2004). Pemberdayaan Kaum Ibu Sebagai Upaya Memutus Mata Rantai Kemiskinan. Mimbar Jurnal Sosial dan Pembangunan, Vol. XXIII. No. 2. (288-299).

Borualogo, Ihsana Sabriani (2006). Optimalisasi Pendidikan Anak Usia Dini (PAUD) Guna Meningkatkan Indeks Pembangunan Manusia (IPM) di Jawa Barat. Mimbar Jurnal Sosial dan Pembangunan, Vol. XXII. No. 3. (394-410).

Borualogo, Ihsana Sabriani (2017). Uji Validitas dan Reliabilitas Alat Ukur CYRM-28 Pada Korban Human Trafficking di Jawa Barat. Prosiding SNaPP Vol. 3, No. 1. (222-226). https://id.usembassy.org.hdr.undp.org

Majalah Tempo (2014). Korban Perdagangan Wanita Terbanyak Dari Jawa Barat. http://nasional.tempo.co/read/ news/2014/12/27/058631158/korbanperdagangan-wanita-terbanyak-dari-jawabarat, diunduh pada 2 Juni 2017.

Ungar, Michael., Liebenberg, Linda., \& Van de Vijver, Fons. (2011). Validation of The Child and Youth Resilience Measure-28 (CYRM28) Among Canadian Youth. Journal of Research on Social Work Practice. DOI: 10.1177/1049731511428619.

Ungar, Michael (2012). The Social Ecology of Resilience - A Handbook of Theory and Practice. New York: Springer.

Van de Vijver, Fons., \& Hambleton, Ronald K. (1996). Translating Tests: Some Practical Guidelines. Journal of European Psychologist, 1, 89-99. Www.unodc.org

Yea, Sallie (2010). Human Trafficking - A Geographical Perspective. Geodate, Vol. 3, No. 3 July 2010. 